\title{
The First Tetra(meso-aryl)porphyrin with Isobornyl Substituents
}

\author{
Dmitry V. Belykh, ${ }^{@}$ Tatiana K. Rocheva, Evgeny V. Buravlev, Irina Yu. Chukicheva, \\ and Alexander V. Kutchin

\begin{abstract}
Institute of Chemistry, Komi Scientific Centre of Ural Division of Russian Academy of Sciences, 167982 Syktyvkar, Russia ${ }^{\circledR}$ Corresponding authorE-mail: belykh-dv@mail.ru
\end{abstract}

The first example of tetra(meso-aryl)porphyrin bearing isobornyl substituents was synthesized by tetrapyrrole condensation from 4-hydroxy-3,5-diisobornylbenzaldehyde and pyrrole.

Keywords: Tetrapyrrole condensation, tetra(meso-aryl)porphyrin, isobornyl subtituents, atropoisomers.

\section{Introduction}

In recent years, much attention is paid to the synthesis of hybrid antioxidants. In this respect the combination of alkyl phenol units with porphyrin macrocycle is rather promising. ${ }^{[1-5]}$ Introduction of several sterically hindered phenol fragments to the periphery of the porphyrin macrocycle can lead to increased antioxidant activity, due to inhibition activity of phenolic moieties in respect to free radicals, and ability of the porphyrin itself to interact with free radicals and oxygen. ${ }^{[6-7]}$ It is known that isobornylphenols possess membrane-protecting properties ${ }^{[8]}$ and can be used as bio- and technical antioxidants. ${ }^{[9]}$ Therefore, the synthesis of porphyrin macrocycles with such substituents is of interest for the synthesis of hybrid antioxidants. In addition, isobornylphenols exhibit anti-inflammatory and hemorheological activity, ${ }^{[10-13]}$ what allows to consider isobornylphenolic fragment as a potential pharmacophore group. In this regard, the introduction of these fragments to the periphery of the porphyrin macrocycle is promising in terms of obtaining new biologically active substances. Thus, the synthesis of hybrid molecules, containing porphyrin macrocycle and the fragments of terpenophenols, is of a great interest.

Here we report on the synthesis of the first tetra(meso-aryl)porphyrin with isobornyl substituents in the aromatic rings by tetrapyrrole condensation of 4-hydroxy-3,5-diisobornylbenzaldehyde with pyrrole (Scheme 1).

\section{Experimental}

IR spectra were recorded on FT-IR spectrometer in tablets with $\mathrm{KBr}$. Electronic absorption spectra (UV-vis) were recorded on a Shimadzu UV-1700 spectrophotometer in $10 \mathrm{~mm}$ quartz cuvettes in dichloromethane. ${ }^{1} \mathrm{H}$ and ${ }^{13} \mathrm{C}$ NMR spectra were recorded on a Bruker Avance II NMR spectrometer (the operating frequency of 300 and $75 \mathrm{MHz}$, respectively) in $\mathrm{CDCl}_{3}$ solutions. Mass spectra were recorded on a MALDI instrument Bruker Ultraflex TOF/ TOF (matrix - dihydroxybenzoic acid). The reaction course was monitored by TLC on Sorbfil plates. For column chromatography aluminum oxide 40/200 micron grade "pure" and silica gel 60/200 micron (Alfa Aesar) were used.

4-Hydroxy-3-\{(1R,2S, 4S)-(1,7,7-trimethylbicyclo[2.2.1] hept-2-yl\}-5-\{(1S,2R,4R)-(1,7,7-trimethylbicyclo[2.2.1] hept-2-yl\} benzaldehyde, 2. Cresol $14.2 \mathrm{~g}(11.03 \mathrm{mmol})$ was dissolved in ${ }^{t} \mathrm{BuOH}(210 \mathrm{ml})$ in the round-bottom flask under slight heating. The mixture was cooled to $\sim 40^{\circ} \mathrm{C}$, and bromine $(1.14 \mathrm{ml}, 22.06$ mmol) was dropped in small portions. The reaction mixture was stirred at room temperature for $3 \mathrm{~h}$ and left overnight. The solvent was evaporated, $45 \mathrm{ml}$ of chloroform was added to dissolve the residue, the solution was washed with saturated aq. $\mathrm{Na}_{2} \mathrm{~S}_{2} \mathrm{O}_{3}(3 \times 25$ $\mathrm{ml})$, water $(2 \times 25 \mathrm{ml})$ and dried over anhydrous $\mathrm{Na}_{2} \mathrm{SO}_{4}$. The solvent was evaporated and the aldehyde 2 was crystallized from petroleum ether. Yield $1.96 \mathrm{~g}(45 \%)$. Colorless powder, m.p. $236-238^{\circ} \mathrm{C}$ (decomp.). Found: C 82.01, $\mathrm{H} 9.86 \%$. $\mathrm{C}_{27} \mathrm{H}_{38} \mathrm{O}_{2}$ (394.59) requires C 82.18; H $9.71 \%$. IR $v \mathrm{~cm}^{-1}: 3397(\mathrm{OH}), 2951,2876\left(\mathrm{Me}, \mathrm{CH}_{2}\right)$, $1670(\mathrm{C}=\mathrm{O}) .{ }^{1} \mathrm{H}$ NMR $\left(\mathrm{CDCl}_{3}\right) \delta_{\mathrm{H}} \mathrm{ppm}: 0.81\left(6 \mathrm{H}, \mathrm{s}, \mathrm{C}^{10,10^{\prime}} \mathrm{H}_{3}\right), 0.85$ $\left(6 \mathrm{H}, \mathrm{s}, \mathrm{C}^{9,9^{\prime}} \mathrm{H}_{3}\right), 0.90\left(6 \mathrm{H}, \mathrm{s}, \mathrm{C}^{8,8^{\prime}} \mathrm{H}_{3}\right), 1.30-1.49,1.53-1.74,1.82-$ 2.04 (per $4 \mathrm{H}$, all m, $\left.\mathrm{H}^{3,3^{\prime}, 4,4^{\prime}}, \mathrm{C}^{5,5^{\prime}} \mathrm{H}_{2}, \mathrm{C}^{6,6^{\prime}} \mathrm{H}_{2}\right), 2.27-2.41\left(2 \mathrm{H}, \mathrm{m}, \mathrm{H}^{3,3^{\prime}}\right)$, $3.00\left(2 \mathrm{H}, \mathrm{t}, \mathrm{H}^{2,2^{\prime}}, J=8.6 \mathrm{~Hz}\right), 5.45(1 \mathrm{H}, \mathrm{s}, \mathrm{OH}), 7.72\left(2 \mathrm{H}, \mathrm{s}, \mathrm{H}^{14,16}\right)$, $9.84(1 \mathrm{H}, \mathrm{s}, \mathrm{CHO}) .{ }^{13} \mathrm{C} \mathrm{NMR}\left(\mathrm{CDCl}_{3}\right) \delta_{\mathrm{C}} \mathrm{ppm}: 12.64\left(\mathrm{C}^{10,10^{\prime}}\right), 20.24$ $\left(\mathrm{C}^{9,9^{\prime}}\right), 21.33\left(\mathrm{C}^{8,8^{\prime}}\right), 27.50\left(\mathrm{C}^{5,5^{\prime}}\right), 34.07\left(\mathrm{C}^{3,3^{\prime}}\right), 40.05\left(\mathrm{C}^{6,6^{\prime}}\right), 45.37$ $\left(\mathrm{C}^{4,4^{4}}\right), 46.07\left(\mathrm{C}^{2,2^{2}}\right), 48.39\left(\mathrm{C}^{7,7^{7}}\right), 50.11\left(\mathrm{C}^{1,1^{\prime}}\right), 128.11\left(\mathrm{C}^{14,16}\right), 128.60$, $129.49\left(\mathrm{C}^{11,13,15}\right), 159.87\left(\mathrm{C}^{12}\right), 191.67(\mathrm{CHO})$.

Tetrakis $\{3-\{(1 R, 2 S, 4 S)-(1,7,7$-trimethylbicyclo[2.2.1]hept2-yl)-5-\{(1S,2R,4R)-(1,7,7-trimethylbicyclo[2.2.1]hept-2-yl\}-4hydroxyphenyl\}porphyrin, 3. Aldehyde 2 ( $1.8 \mathrm{~g}, 4.56 \mathrm{mmol})$ was dissolved under slight heating in $20 \mathrm{ml}$ of propionic acid, 0.32 $\mathrm{ml}(4.56 \mathrm{mmol})$ of pyrrole was added and the mixture was added dropwise to $20 \mathrm{ml}$ of boiling propionic acid. The solution was refluxed for $0.5 \mathrm{~h}$ and cooled. The reaction mixture was left at room temperature in air for 7 days. The precipitate was filtered, washed with hexane and water, dried on air and purified by column chromatography consecutively on $\mathrm{Al}_{2} \mathrm{O}_{3}$ and $\mathrm{SiO}_{2}$ (eluent - chloroform). Purple crystalline powder was obtained. Yield $0.38 \mathrm{~g}(19 \%)$. UV-vis $\left(\mathrm{CH}_{2} \mathrm{Cl}_{2}\right) \lambda \mathrm{nm}: 653.0,595.5,560.5,522.5$, 462.0, 424.5, 418.5. $\mathrm{m} / \mathrm{z}$ (MALDI): $1768.265[\mathrm{MH}]^{+}$, calculated 1768.236. ${ }^{1} \mathrm{H}$ NMR $\left(\mathrm{CDCl}_{3}\right) \delta_{\mathrm{H}} \mathrm{ppm}:-2.65(2 \mathrm{H}$, br s, NH), 0.92 $\left(24 \mathrm{H}\right.$, br s, $\left.\mathrm{C}^{10,10^{\prime}} \mathrm{H}_{3}\right), 0.99 / 1.00 / 1.02 *\left(24 \mathrm{H}, \mathrm{s}, \mathrm{C}^{9,9^{\prime}} \mathrm{H}_{3}\right), 1.18(24 \mathrm{H}$, $\left.\mathrm{s}, \mathrm{C}^{8,8^{\prime}} \mathrm{H}_{3}\right), 1.37-2.06\left(48 \mathrm{H}, \mathrm{m}, \mathrm{H}^{3,3^{\prime}, 44^{\prime}}, \mathrm{C}^{5,5^{\prime}} \mathrm{H}_{2}, \mathrm{C}^{6,6^{\prime}} \mathrm{H}_{2}\right), 2.30-2.48$ $\left(8 \mathrm{H}, \mathrm{m}, \mathrm{H}^{3,3^{\prime}}\right), 3.39\left(8 \mathrm{H}, \mathrm{br} \mathrm{t}, \mathrm{H}^{2,2^{\prime}}, J=\sim 8.0 \mathrm{~Hz}\right), 5.25 / 5.26^{*}(4 \mathrm{H}$, s, OH), 8.08/8.09* (8H, s, H $\left.{ }^{14,16}\right), 8.81 / 8.83 / 8.85 / 8.89 *(8 \mathrm{H}, \mathrm{s}$, $\left.\mathrm{H}^{\beta}\right)$. Asterisk $(*)$ denotes the resolved signals of the individual atropoisomers. 
Tetraarylporphyrin with Isobornyl Substituents

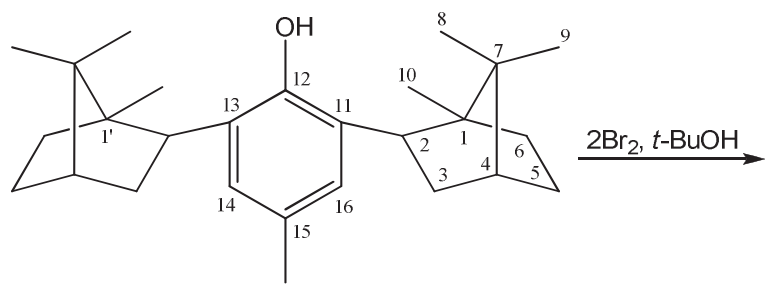

1

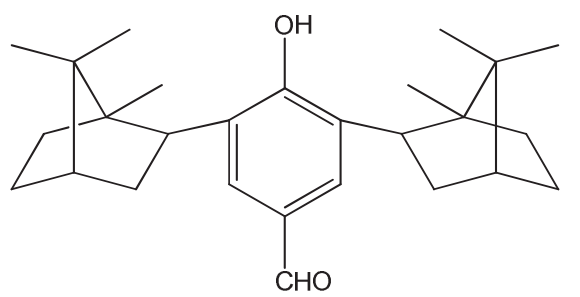

2

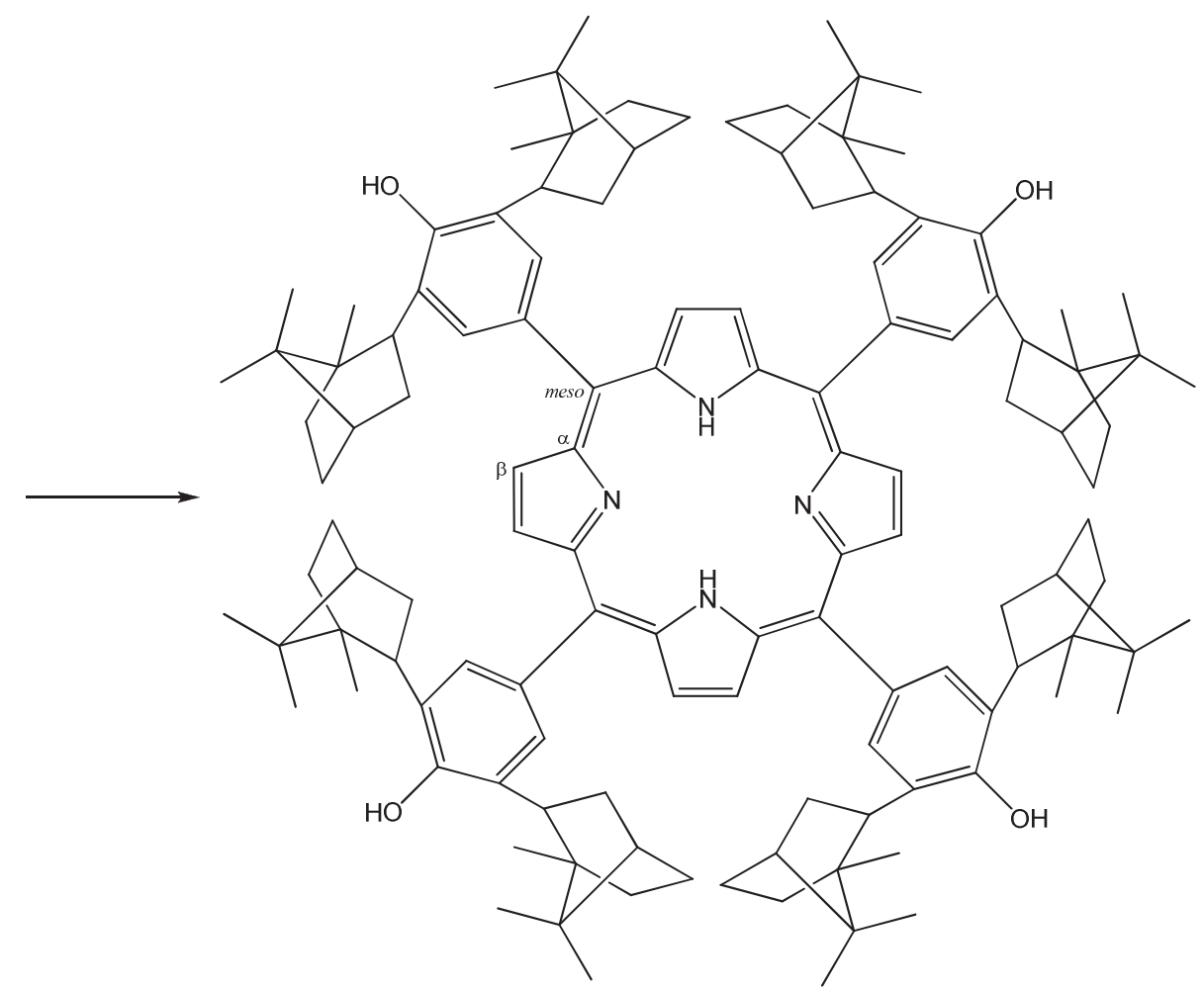

3

Scheme 1.
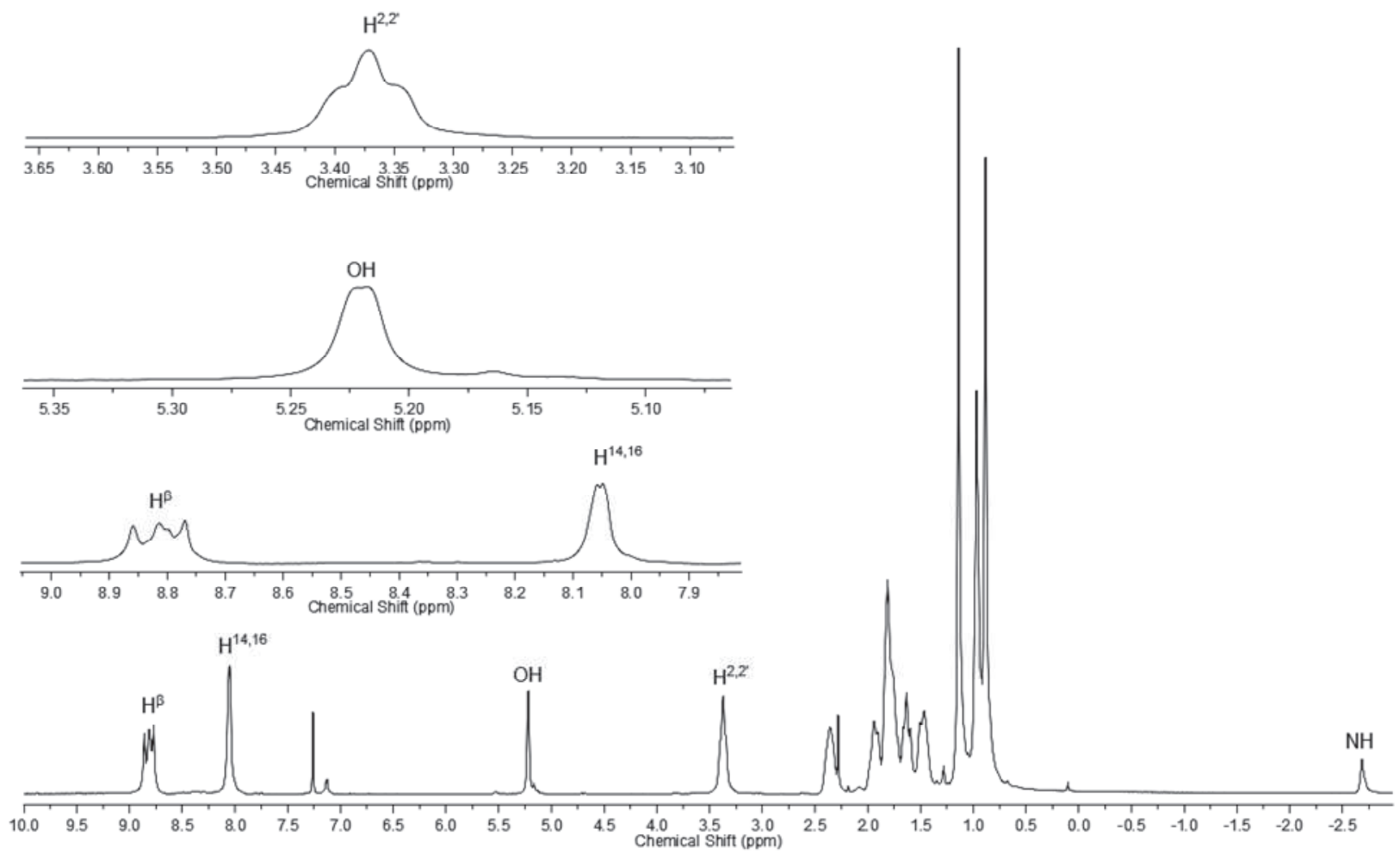

Figure 1. ${ }^{1} \mathrm{H}$ NMR spectrum of compound 3 in $\mathrm{CDCl}_{3}$. 


\section{Results and Discussion}

4-Hydroxy-3,5-diisobornylbenzaldehyde 2 was received by oxidation of methyl group in compound 1 with bromine in tert-butanol by the procedure described for the synthesis of 4-hydroxy-3,5-di-tert-butylbenzaldehyde. ${ }^{[14]}$ Tetrapyrrole condensation with the aldehyde 2 was carried out by a procedure similar to the synthesis of tetra(mesophenyl)porphine - in boiling propionic acid at large dilution with following slow oxidation by atmospheric oxygen. ${ }^{[15]}$ The structure of the obtained porphyrin $\mathbf{3}$ was confirmed by NMR, UV-vis and IR spectroscopy and mass spectrometry. The mass spectrum of the compound contains peak with $\mathrm{m} / \mathrm{z}$ $=1768.265$, corresponding to the protonated molecular ion $\left[\mathrm{MH}^{+}\right] .{ }^{1} \mathrm{H}$ NMR spectrum of product 3 contains well resolved signals of the proton of porphyrin macrocycle (the signals corresponding to pyrrolic $\mathrm{H}^{\beta}$ protons at $8.95-8.70 \mathrm{ppm}$ and a broadened singlet, corresponding to the protons of the inner $\mathrm{NH}$ groups at $-2.65 \mathrm{ppm}$ ), and the signals of protons in the terpenophenol groups (the singlets, corresponding to $\mathrm{H}^{14,16}$ protons at 8.08-8.09 ppm and to hydroxyl group protons at $5.23 \mathrm{ppm}$, as well as multiplets of terpene substituents in the 3.4-0.8 ppm region) (Figure 1).

The ratio of integrated intensities of signal belonging to protons of the porphyrin macrocycle and terpenophenol substituents corresponds to the expected for tetrasubstituted macrocycle. The formation of the porphyrin macrocycle was also confirmed by UV-vis spectroscopy: the electronic absorption spectrum contains the Soret band and the bands characteristic of the tetra-meso-substituted porphyrin chromophore in the visible region.
It is known, that for meso-arylporphyrins, atropoisomerism is possible in the case of hindered rotation of the aryl substituents. ${ }^{[16]}$ Very likely, the similar atropoisomerism is realized in the case of porphyrin $\mathbf{3}$, in which diisobornylphenol substituents are quite large and create a difficulty in rotation around the bonds $\mathrm{C}^{15}-\mathrm{C}^{\text {meso }}$. Possible atropoisomers (A-D) of the compound $\mathbf{3}$ are schematically shown in Figure 2.

The presence of atropoisomers is confirmed by NMR spectroscopy. In the ${ }^{1} \mathrm{H}$ NMR spectrum of compound 3 the signals corresponding to pyrrolic $\mathrm{H}^{\beta}$ protons of each of the four atropoisomers are observed; a small splitting is seen also for the signals of $\mathrm{H}^{14}, \mathrm{H}^{16}$ and $\mathrm{OH}$ protons (Figure 1). In addition, a broadening of the signals of the other protons could also be due to small deviations of the spectral characteristics of different atropoisomers.

\section{Conclusion}

Thus, in this paper we propose a simple method for the synthesis of tetra(meso-aryl)porphyrin with diisobornylphenol substituents on the basis of 4-hydroxy3,5-diisobornylbenzaldehyde by tetrapyrrole condensation.

Acknowledgments. The work was supported by the Ural Branch of Russian Academy of Sciences (competition of scientific projects of young scientists and graduate students of UB RAS, project 11-3-NP-266) and the Russian Academy of Sciences (basic research, carried out under the program "Medical and Biomolecular Chemistry", project 12-T-31020).

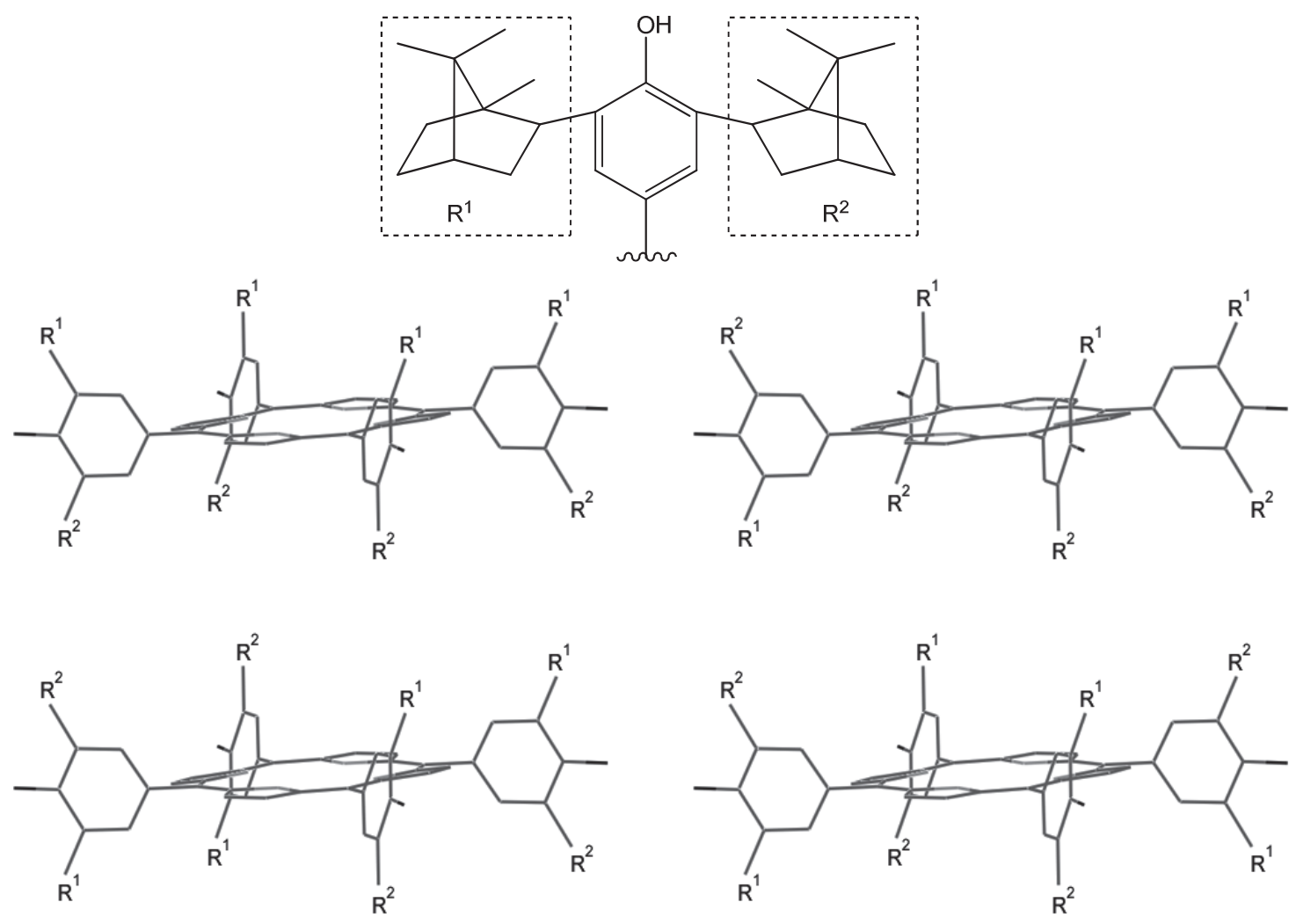

Figure 2. Possible atropoisomers of the compound 3. 


\section{References}

1. Milaeva E.R. Russ. Chem. Bull., Int. Ed. 2001, 50, 573-586.

2. Gerasimova O.A., Shpakovsky D.B., Milaeva E.R., Louloudi M., Hadjiliadis N. Moscow Univ. Chem. Bull. 2007, 62, 264-268.

3. Gerasimova O.A., Milaeva E.R., Shpakovsky D.B., Semeikin A.S., Syrbu S.A. Russ. Chem. Bull., Int. Ed. 2007, 56, 831834.

4. Milaeva E.R., Gerasimova O.A., Zhang Jingwei, Shpakovsky D.B., Syrbu S.A., Semeykin A.S., Koifman O.I., Kireeva E.G., Shevtsova E.F., Bachurin S.O., Zefirov N.S. J. Inorg. Biochem. 2008, 102, 1348-1358.

5. Antonova N.A., Osipova V.P., Kolyada M.N., Movchan N.O., Milaeva E.R., Pimenov Yu.T. Macroheterocycles 2010, 3, 140144.

6. Koifman O.I., Ageeva T.A. Porfirinopolimery [Porphyrin polymers]. Moskva: Izdatel'stvo fiziko-matematicheskoi literatury, 2006, 194 p. (in Russ.).

7. Tarasevich M.R., Radyushkina K.A. Kataliz i elektrokataliz metalloporfirinami [Catalysis and Electrocatalysis by Metalloporphyrins]. Moskva: Nauka, 1982, 168 p. (in Russ.).

8. Buravlev E.V., Chukicheva I.Yu., Shevchenko O.G., Suponitsky K.Yu., Kutchin A.V. Russ J. Bioorg. Chem. 2011, 37, 614-618.
9. Chukicheva I.Yu., Buravlev E.V., Fedorova I.V., Borisenkov M.F., Kutchin A.V. Russ. Chem. Bull., Int. Ed. 2010, 59, 22762280.

10. Cirri M., Mura P., Corvi Mora P. Int. J. Pharm. 2007, 30, 8491.

11. Chukicheva I.Yu., Fedorova I.V., Buravlev E.V., Lumpov A.E., Vikharev Yu.B., Anikina L.V., Grishko V.V., Kuchin A.V. Chem. Nat. Compd. 2010, 46, 478-480.

12. Plotnikov M.B., Smol'yakova V.I., Ivanov I.S., Kuchin A.V., Chukicheva I.J., Buravlev E.V., Krasnov E.A. Pharm. Chem. J. 2011, 44, 530-533.

13. Buravlev E.V., Chukicheva I.Y., Suponitsky K.Y., Vikharev Y.B., Grishko V.V., Kutchin A.V. Lett. Org. Chem. 2011, 8, 301-308.

14. Coppinger G.M., Campbell T.W. J. Am. Chem. Soc. 1953, 75, 734-736

15. Porfiriny: Struktura, svoistva, sintez [Porphyrins: Structure, Properties, Synthesis] (Enikolopyan N.S., Ed.). Moskva: Nauka, 1985, 334 p. (in Russ.).

16. Koifman O.I., Mamardashvili N.Zh., Antipin I.S. Sinteticheskie retseptory na osnove porfirinov i ikh kon'yugatov s kaliks [4] arenami [Synthetic Receptors Based on Porphyrins and Their Conjugates with Calix[4]arenes]. Moskva: Nauka, 2006, 246 p. (in Russ.). 